\title{
Quantitative Determination of Diphenhydramine and Orphenadrine in Human Serum by Capillary Gas Chromatography
}

\author{
By D. Lutz, W. Gielsdorf and H. Jaeger \\ L.A.B. Gesellschaft für pharmakologische Untersuchungen, Neu-Ulm
}

(Reccived February 14/May 4, 1983)

Summary: Diphenhydramine has been in medical use for 35 years as an antihistamine and hypnotic. We evaluated the pharmacokinetic parameters, which are not only important for disposition studies, in the serum of 10 volunteers who received a single dose of $31 \mathrm{mg}$ diphenhydramine.

For this purpose a suitable capillary GC-method was developed, which has a detection limit of $2 \mu \mathrm{g} / 1$ (serum); the calibration curve is linear between 2.5 and $120 \mu \mathrm{g} / \mathrm{l}$, the reproducibility is always better than $3.6 \%$ and the average recovery is about $100.1 \%$.

The combination of a relatively non-polar extraction solvent, a selective detector (N-FID) and a fused silica, bonded-phase capillary column led to a more rapid sample clean-up procedure (no back-extraction needed) and is sensitive and specific enough for the quantitative determination of diphenhydramine, orphenadrine or other ethanolamines in human serum.

Quantitative Bestimmung von Diphenhydramin und Orphenadrin im Serum des Menschen durch Kapillar-Gaschromatographie

Zusammenfassung: Diphenhydramin findet seit über 35 Jahren als Antihistaminicum und Hypnoticum medizinische Verwendung. Wir bestimmten die nicht nur für pharmakologische Studien wichtigen pharmakokinetischen Kenngrößen im Serum von 10 Probanden nach Gabe einer Einzeldosis von $31 \mathrm{mg}$ Diphenhydramin.

Hierzu entwickelten wir eine geeignete kapillar-gaschromatographische Methode mit einer Nachweisgrenze von $2 \mu \mathrm{g} / \mathrm{l}$ Serum; die Kalibrierungskurve ist linear zwischen 2,5 und $120 \mu \mathrm{g} / \mathrm{l}$, die Wiederholbarkeit immer besser als $3,6 \%$ und die Wiederfindungsrate lag bei $100,1 \%$.

Die Kombination eines relativ unpolaren Lösungsmittels zur Extraktion mit einem selektiven Detektor (NFID) und einer fused-silica, bonded phase-Kapillare führt, da keine Rückextraktion benötigt wird, zu kürzeren Probenaufbereitungszeiten und ist empfindlich und spezifisch genug für die quantitative Bestimmung von Diphenhydramin, Orphenadrin und anderen Ethanolaminen im menschlichen Serum.

\section{Introduction}

For well over 35 years diphenydramine hydrochloride (I)* has been used medically as an antihistamine and hypnotic (1).

Chemically it is 2-(diphenylmethoxy)-N,N-dimethylethylamine and possesses anticholinergic, antitus-

\footnotetext{
* in the U.S.: Benadryl (Parke-Dạvis)

in Germany: Betadorm-A (Woelm Pharma)

in Switzerland: Detensor (Sandoz)

sive, antiemetic and sedative properties, the last mentioned leading to its widespread use as a drug for inducing sleep $(2,3)$ :

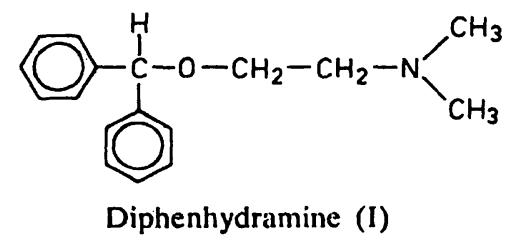


Diphenhydramine is rapidly and well absorbed with a systemic bioavailability of at least $50 \%$ after oral application $(4,5)$. Maximal plasma concentrations are reached after one to four hours $(6,7)$; an apparent plasma half-life of about 3-10 hours is reported (4).

Average peak plasma levels (after a therapeutic dose of $50 \mathrm{mg}$ ) were about $80-100 \mu \mathrm{g} / \mathrm{l}(3-7)$. The biotransformation of $I$ is well documented in the literature (8); the major metabolite in human plasma and urine was identified as diphenylmethoxyacetic acid (9).

\section{Analytical Methods}

Many analytical approaches have been published for the identifi= cation/detection of diphenhydramine, e.g. paper-, thin layer- and column-chromatography, electrophoresis, colorimetric/fluorometric and titrimetric analysis (10-12). These, however are not specific and sensitive enough for determinations in biological fluids (urine, plasma/serum).

The published GC, GC-MS and HPLC-methods are obviously more reliable. Unfortunately they often include extensive, time consuming preparations (e.g. special sample clean-up), involving conversion or formation of derivatives (13) and/or operate near the limit of sensitivity. Some methods do not distinguish between the unchanged drug and its metabolites or are prone to interferences (6).

All the published GC-methods use packed columns and flame ionization detectors (FID), which limits sensitivity to about $10-20 \mathrm{mg} / \mathrm{l}(2,4,7,11,14)$; recently published methods employ more selective detectors, e.g. the nitrogen specific detector $(\mathrm{N}$ FID) (6).

Vessman et al. (13) successfully used the electron capture detector (ECD), but their sample clean-up includes e.g. conversion of diphenhydramine to benzophenone, a rather time-consuming and inconvenient procedure. Liquid-chromatographic assays have only been applied to aqueous samples and/or are not applicable for rapid (screening) procedures $(15,16)$. The published gas chromatographic-mass fragmentographic method using single-ion-recording (SIR) of the characteristic ion at $\mathrm{m} / \mathrm{z} 165$ fulfills the requirements for a reliable assay but is less suitable for some metabolites (e.g. the $\mathrm{N}$-oxide and the diphenylmethoxyacetic acid) which are either thermolabile or not volatile enough $(17,18)$; furthermore this method is relatively expensive and often not readily. available in a clinical laboratory.

\section{Results and Discussion of our own investigations}

With some exceptions we followed the GC-method published by Baugh \& Calvert (7); a five-fold increase of the detection limit could be achieved by employing a capillary column instead of a packed column.

\section{Extraction}

To $3 \mathrm{ml}$ of serum in a centrifuge tube (fitted with a teflon lined cap) $10 \mu \mathrm{l}$ of a methanolic solution of the internal standard (14 $\mu \mathrm{g} / \mathrm{l})$ are added and thoroughly mixed (Vortex) for 10 seconds.
After adding $1 \mathrm{ml}$ of sodium hydroxide $(1 \mathrm{~mol} / \mathrm{l})$ and $7 \mathrm{ml} n$-heptane, the mixture is extracted for one hour in an inversion shaker. After centrifuging, the organic layer is transferred to a conical tube and evaporated to dryness under nitrogen at $55^{\circ} \mathrm{C}$. The residue is reconstituted in $40 \mu \mathrm{l}$ acetone, concentrated to approx. 10 $\mu l$ and $1 \mu l$ is injected in the GC.

\section{GC-conditions}

if

The GC analysis is carried out using a Carlo Errba FV 2150 chromatograph equipped with an nitrogen selective detector (N-FID).

Column:

$30 \mathrm{~m} \times 0.25 \mathrm{~mm}$ fused silica, bonded phase DB-1 capillary column $(J+W$ Scientific)

Carrier gas:

He 1.2 bar

Make-up gas:

$\mathrm{N}_{2} 0.4$ bar

Hydrogen:

$3 \mathrm{ml} / \mathrm{min}$

Air:

$100 \mathrm{ml} / \mathrm{min}$

Temperatures: injector: $200^{\circ} \mathrm{C}$

oven: $50^{\circ} \mathrm{C}(1 \mathrm{~min})$ to $180^{\circ} \mathrm{C}$ for $5 \mathrm{~min}$ then at a rate of $6^{\circ} \mathrm{C} / \min$ to $210^{\circ} \mathrm{C}$.

The quantitative evaluation of the serum samples was accomplished by comparison with the respective peak area ratios of the spiked serum samples ("Internal Standard Method").

Figure $1 \mathrm{a}$ and $\mathrm{b}$ show two representative chromatograms of a serum extract before and after drug treat= ment.

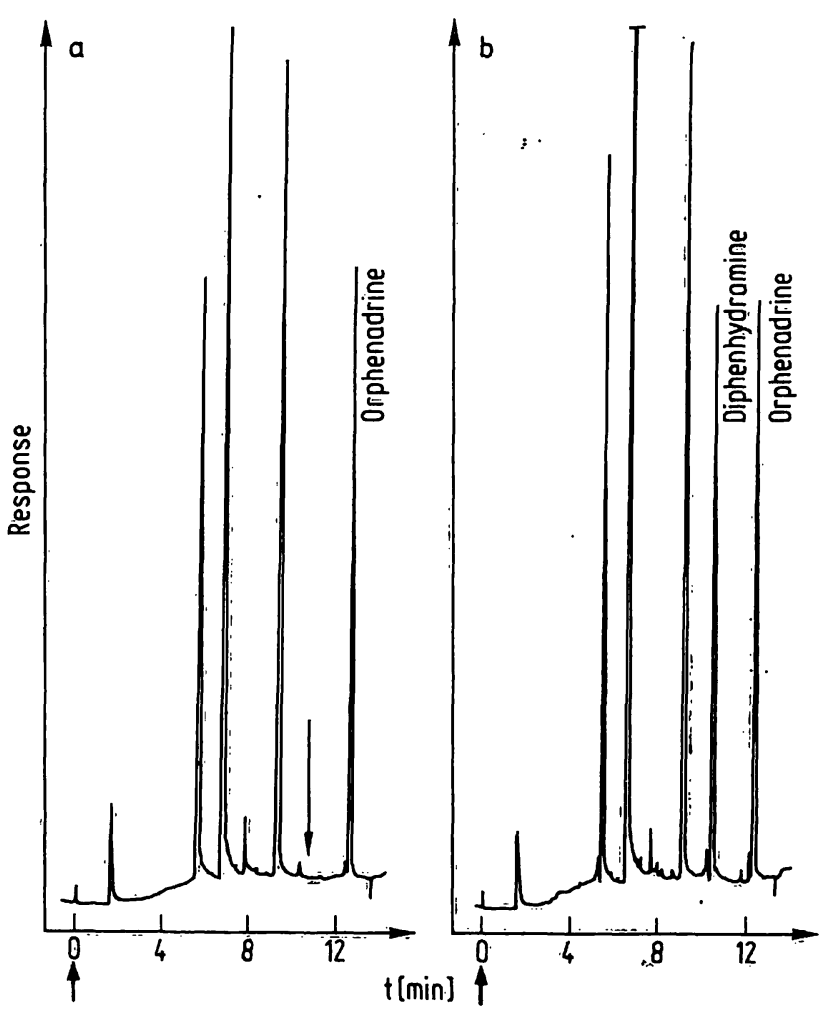

Fig. 1. Chromatograms of plasma extracts

a) Drug-free plasma with internal standard orphenadrine b) Four hours after receiving $31 \mathrm{mg}$ diphenydramine 
Figure 2 shows the serum concentration-time curve of diphenhydramine in 10 volunteers following a single oral dose of $31 \mathrm{mg}$.

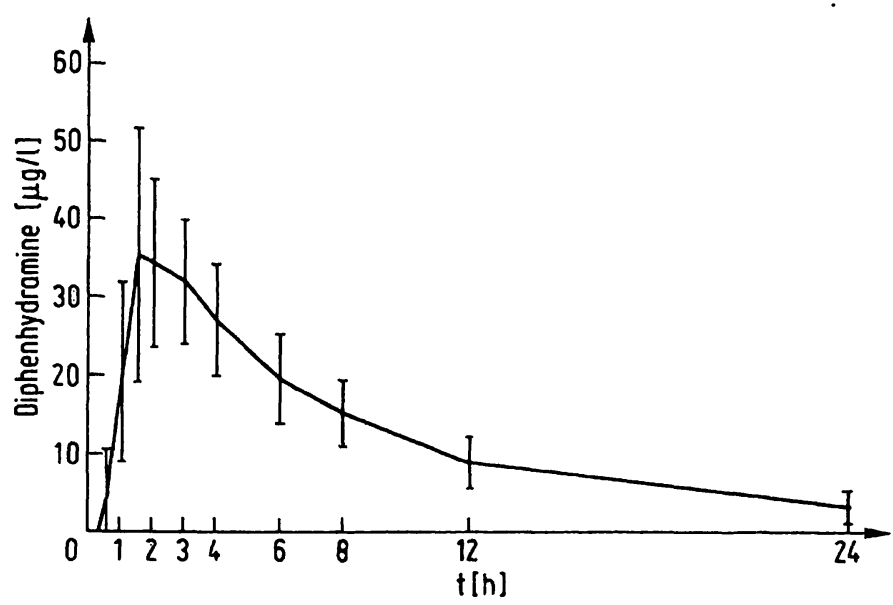

Fig. 2. Mean serum concentrations (incl. standard deviation) of diphenhydramine of 10 volunteers after ingestion of 31 $\mathrm{mg}$.

\section{References}

1. Goodman, L. S. \& Gilman, A. (eds.) (1975) The Pharmacological Basis of Therapeutics, 5 th ed. Macmillan Publishing Co., New York.

2. Külpman. W. R. \& Schreiber, M. (1981) J. Clin. Chem. Clin. Biochem. 19, 740.

3. Carruthers, S. G., Shoeman, D. W., Hignite, D. E. \& Azarnoff, D. L. (1978) Clin. Pharmacol. Ther. 23, 375-382.

4. Albert, K. S., Hallmark, M. R., Sakmar, E., Weidler, D. J. \& Wagner, J. G. (1975) J. Pharmacokin. Biopharmaceut. 3, 159-170.

5. Carruthers, S. G., Shoeman, D. W. \& Azarnoff, D. L. (1976) Res. 34, 562 A.

6. Bilzer, W. \& Gundert=Remy, V. (1973) Eur. J. Clin. Pharmacol. 6, 268-270.

7. Baugh, R. \& Calvert, R. T. (1976) Br. J. Clin. Pharmacol. 3, 1062-1064.

8. Pfeifer, S. (1976) Biotransformation von Arzneimitteln, Verlag Chemie, Weinheim/New York.

9. Chang, T., Okerholm, R. A. \& Glazko, A. J. (1974) Chem. Pathol: Pharmacol. 9, 391-404.

\section{Conclusions}

The presented capillary GC-method allows the fast and accurate quantitative determination of either diphenhydramine or orphenadrine and other ethanolamines in human serum. It is also clear from the chromatogram (fig. 1) that capillary columns provide more than adequate efficiency, sensitivity and selectivity.

The combination of a rather non-polar extraction solvent and a selective detector eliminates the need for e.g. a back extraction or further steps in sample clean-up.

A calibration curve was established and checked to be linear between 2.5 and $120 \mu \mathrm{g} / 1$ serum; the detection limit of $2 \mu \mathrm{g} / \mathrm{l}$ clearly shows the reliability of the assay. Average recovery based on 5 determinations (at $14 \mu \mathrm{g} / \mathrm{l}$ ) was about $100.1 \%$ (C.V. $=4.9 \%$ ); reproducibility between duplicate injections was always better than $3.6 \%$.

10. Holcombe, I. J. \& Fusari, S. A. (1974) In: Analytical Profiles of Drug Substances, Vol. 3 (Florey, K., ed.), Academic Press, New York.

11. Raeder-Schikorr, M. (1980) In: Drug Level Monitoring (Sa- dée, W. \& Beelen, G. C. M., eds.) J. Wiley, New York.

12. Müller, R. K. (1976) Die toxikologisch-chemische Analyse, Verlag Chemie, Weinheim/New York.

13. Vessmann, J., Hartvig, P. \& Stromberg, S. (1970) Acta Pharm. Suecica 7, 373-375.

14. Siek, T. J. (1975) In: Methodology for Analytical Toxicology (I. Sunshine, ed.) CRC Press Inc., Cleveland.

15. Bergh, M. L. E. \& de Vries, J. (1980) J. Liq. Chrom. 3, 1173-1181.

16. Vandemark, F. L., Adams, R. F. \& Schmidt, G. J. (1978) Clin. Chem. 24, 87-91.

17. Eckard, R., Ening, R. \& Ening, W. (1978) Arch. Pharmacol. 302, Suppl., 14.

18. Cailleux, A., Turcant, A., Premel-Cabic, A. \& Allican, P. (1981) J. Chrom. Sci. 19, 163-176.

Dr. W. Gielsdorf

L.A.B. Gesellschaft für

pharmakologische Untersuchungen m.b.H.

Brühlweg 23

D-7910 Neu-Ulm 4 
